\title{
Water Stress Tolerance, Its Relationship to Stem Reserve Mobilization and Potence Ratio in Spring Wheat
}

\author{
Ijaz Rasool Noorka ${ }^{1,2^{*}}$, Amarah Batool ${ }^{1}$, Sultan AlSultan ${ }^{3}$, Saba Tabasum ${ }^{1}$, Amjed Ali ${ }^{1}$ \\ ${ }^{1}$ University College of Agriculture, University of Sargodha, Sargodha, Pakistan; ${ }^{2}$ Molecular Cytogenetics Lab, University of Leices- \\ ter, Leicester, UK; ${ }^{3}$ Qassim University, College of Agriculture, Al Qassim, KSA. \\ Email: *ijazphd@yahoo.com
}

Received December $15^{\text {th }}, 2012$; revised January $15^{\text {th }}, 2013$; accepted January $23^{\text {rd }}, 2013$

\begin{abstract}
Twelve wheat (Triticum aestivum L.) cultivars and their sixteen direct and reciprocal crosses were evaluated for heterosis, heterobeltiosis and potence ratio to determine the potential of wheat genotypes under contrasting water regimes. The highest positive heterosis and heterobeltiosis was observed in cross combination Sehr-06 $\times$ Pasban-90 under both water regimes for the trait stem reserve mobilization (SRM). While in trait 1000-grain weight the cross- combination Pari-73 $\times$ C-273 (Normal irrigation) and Fsd-08 $\times$ SA-42 (water stress) showed highest heterosis and Pari-73 $\times$ C-273(Normal irrigation) and Fsd-08 $\times$ Chenab-70(water stress) showed highest value of heterobeltiosis. The potence ratio in both traits expressed overdominance estimates exhibiting the presence of transgressive segregants, may be exploited for on-ward selection in the bread wheat improvement. The genotypes showing better SRM based 1000-grain weight in the absence of photosynthesis indicates relative water stress tolerance. This procedure paved an indirect way to screen the wheat genotypes to withhold water stress situation and sustain wheat production.
\end{abstract}

Keywords: Stem; Reserve; Mobilization; Direct; Reciprocal

\section{Introduction}

Wheat is ranked as a staple food of most of world parts particularly in Pakistan due to cheap source nutrition since decades. The major part of wheat grain is consumed by humans and livestock while remaining parts for other by products. Twenty percent diet calories of the world is provided by wheat grain [1]. It pertains $70 \%$ carbohydrates, $12 \%$ protein, $22 \%$ crude fibers, $2 \%$ fat, $12 \%$ water and $1.8 \%$ minerals [2]. Its diverse cultivation in geographic center of origins has evidences for more than 10,000 years as described by Sleper and Poehlman [3]. So, in Pakistan wheat is considered as a versatile crop due to its quantum contributions of 14.4 percent agricultural value addition and 3.1 percent to country GDP. The area and production targets of wheat since last year have shown a decline of 0.04 percent. The estimated size of wheat crop is 23,864 million tons showing $0.7 \%$ downward trend than last year [2]. Employment of heterosis isconsidered as an effective strategy to overcome the stagnant yield barrier to feed the burgeoning population [4]. Heterosis is considered as the increase or decrease in vigour of hybrids as compared to their parents.

${ }^{*}$ Corresponding author.
Sharif et al. [5], Kumar et al. [6] concluded that heterosis is not only limited to cross pollinated crops but can be employed in self-pollinated crop like wheat to exploit its potential. Under the changing climatic situation, water is expected to be limited and it will be the prime factor to produce food security [7-10]. The development and growth of wheat grain mainly depends on current assimilates that are partitioned in to the grains $[11,12]$. Stem reserve mobilization is also an important index of drought. A genotype having higher capacity to mobilize its reserves may be considered to show good performance under drought stress. Gupta et al. [13] showed that drought tolerant genotypes of wheat have the higher capacity to mobilize its nutrients under drought stress. In wheat, it is pertinent to improve the grain filling capacity by stem and spike reserves to combat the water stress as breeding strategy $[14,15]$. Water always have the prime importance in our food security system and its proper management leads to water saving [16]. Ourprincipal objective was to estimate the level of heterosis and heterobeltiosis for grain weight as well as stem reserve mobilization among $\mathrm{F}_{1}$ hybrids andrespective parents under two different, normal irrigation and water stress condition. Other objective was to devise a possible screening 
methodology for the stem reserve mobilization trait to address the water stress tolerance in wheat.

\section{Materials and Methods}

\subsection{Purpose of Study}

The present study was carried out to estimate the magnitude of heterosis for grain weight and stem reserve mobilization to reckon the level of water stress tolerance in wheat.

\subsection{Study Site}

The research was initiated in the experimental area of University College of Agriculture, University of Sargodha during the crop season 2009-2011.

\subsection{Genetic Material}

Twelve wheat genotypes were used to initiate the researchviz; Sehr-06, Pasban-90, C-273, Pari-73, SA-42, Fsd-08, Chenab-70, Blue Silver, Lasani-08, Pak-81, Uqab2000, and Pothowar-73 with diverse origin wheat genotypes (Table 1). The genotypes were sown in crossing block during the 15 th of October, 2010 by a hand drill. At the flowering stage, 110 days after sowing (DAS) the $\mathrm{F}_{1}$ hybrids including direct crosses and their reciprocals were attempted by hand emasculation of anther and covered with butter paper bag to avoid foreign pollen contaminations. The mature bifid stigmas of female lines

Table 1. Pre-green revolution and post green revolution selected wheat varieties pedigree.

\begin{tabular}{|c|c|c|c|}
\hline $\begin{array}{c}\text { Wheat } \\
\text { varieties }\end{array}$ & Parentage & $\begin{array}{c}\text { Research } \\
\text { Institute/Station }\end{array}$ & $\begin{array}{l}\text { Year of } \\
\text { Release }\end{array}$ \\
\hline $\mathrm{C} 273$ & C209/C591 & $\begin{array}{c}\text { Punjab.Agri. } \\
\text { C.Res.Inst.Lyallpur }\end{array}$ & 1957 \\
\hline Chenab 70 & C271-WT(E)//SON 64 & AARI.Faisalabad & 1970 \\
\hline SA 42 & C271-LR64/SON 64 & -do- & 1971 \\
\hline Blue Silver & $\begin{array}{c}\text { II-54-388-AN(YT.54-N } \\
\text { 10B/LR 64) }\end{array}$ & RARI, Bahawalpur & 1971 \\
\hline Pothowar & 114B-35/NAD 63 & -do- & 1973 \\
\hline Pari 73 & $\begin{array}{c}\text { CNO'S'//SON/KL.REND } \\
\text { /M.PAK }\end{array}$ & -do- & 1973 \\
\hline Pak-81 & $\mathrm{KVZ} / \mathrm{BUHO} / / \mathrm{KAL} / \mathrm{BB}$ & - do- & 1981 \\
\hline Pasban-90 & $\begin{array}{c}\text { INIA66/A.DISTT//INIA } \\
\text { 66/3/GEN81 }\end{array}$ & WRI, Faisalabad & 1990 \\
\hline Uqab-2000 & CROW'S'/NAC//BOW'S' & WRI, Faisalabad & 2000 \\
\hline Lasani-08 & LUAN/KOH-97 & WRI, Faisalabad & 2008 \\
\hline Faisalabad- 08 & PBW62/2*PASTOR & WRI, Faisalabad & 2008 \\
\hline Sehr-06 & $\begin{array}{c}\mathrm{CHILL} / 2^{*} \mathrm{STAR} / 4 / \mathrm{BOW} / \\
\mathrm{CROW} / / \mathrm{BUC} / \mathrm{PVN} / 3 /\end{array}$ & WRI, Faisalabad & 2006 \\
\hline
\end{tabular}

Source. CIMMYAT, 1989. were pollinated manually with the help of camel brush approximately after three days. Suitable tags were hanged to maintain identity of each cross.

\subsection{Hybridization}

The crosses were made by hand emasculation and pollination. The lists of crosses are as given as Sehr-06 $\times$ Pasban-90,Pasban-90 $\times$ Sehr-06, C-273 $\times$ Pari-73, Pari-73 $\times$ C-273, SA-42 $\times$ Fsd-08, Faisalbad-2008 $\times$ SA-42, FS-08 $\times$ Chenab-70, Chenab-70 $\times$ FS-08, Sehr-06 $\times$ Blue Silver, Blue Silver $\times$ Sehr-06, Lasani-08 $\times$ Pak-81, Pak-81 $\times$ Lasani-08, Uqab-2000 $\times$ Pothowar-73, Pothowar-73 $\times$ Uqab-2000, Pak-81 × Pasban-90, Pasban-90 × Pak-81.

\subsection{Water Stress}

The seeds of all crosses and respective parents was taken and sown in the next crop season (2010-2011) in pots with three replications using completely randomized design (CRD) in contrasting water regimes in two sets of experiment. The pots were placed under plastic sheet driven belt to save from occasional rains. One set was kept under normal irrigation system by maintaining the soil moisture close to field capacity (17\% moisture content $\mathrm{w} / \mathrm{w}$ ), while the second set irrigation was with held up to half during reproductive phase. After 163 DAS, when crop was at maturity, the data were taken.

\subsection{0-Grain Weight (g)}

Fixed number of grains was taken from each plant and 1000-grain weight was estimated by multiplicationmethod.

\subsection{Stem Reserve Mobilization}

At maturity the main stem having spike was harvested. Leaves were removed and then dried to constant weight. Afterwards stem reserve mobilization was estimated according to the Formula (1) below [13].

$$
\text { Stem reserve mobilization }=\frac{\text { grain yield per plant }}{\text { Dry stem weight }}
$$

\subsection{Statistical Analysis}

To estimate significant differences among parents and hybrids, the data were subjected to statistical analysis by using the analysis of variance technique in completely randomized design with two factors i.e., genotypes and water regimes [17]. Significant differences were further subjected to least significance difference test (LSD).

\subsection{Heterosis and Heterobeltiosis}

The percent increase or decrease of $F_{1}$ hybrids over mid 
parent as well as better parent value was calculated to estimate possible heterotic effects following Formulae, (2) and (3) given by Fonceca and Patterson [18].

$$
\begin{aligned}
& \text { \%age } H t=\frac{F_{1}-M . P}{M . P} \times 100 \\
& \text { \%age } H b t=\frac{F_{1}-B . P}{B . P} \times 100
\end{aligned}
$$

where, $H t=$ Heterosis, $H b t=$ Heterobeltiosis, $M . P=$ Mid Parent Value, B.P = Better parent Value.

\subsection{Potence Ratio}

The potence ratio was calculated by the following Formula (4):

$$
\text { Potence ratio }=\frac{F_{1}-M . P}{B . P-M . P}
$$

" $\mathrm{t}$ " Test, The ' $\mathrm{t}$ ' test was manifested to determine whether $F_{1}$ hybrid means were statistically different from mid parent and better parent value. The t-value for heterosis was calculated following the Formula (5)

$$
t_{i j}=F_{1 i j}-M \cdot P_{i j}(3 / 8 E M S)^{1 / 2}
$$

The $\mathrm{t}$-value for heterobeltiosis was calculated following the Formula (6)

$$
t_{i j}=F_{1 i j}-B \cdot P_{i j}(1 / 2 E M S)^{1 / 2}
$$

where $F_{1 i j}=$ The Mean of the ijth $F_{1}$ cross, M.P $P_{i j}=$ The mid parent for the $i j$ th cross.

B. $P_{i j}=$ The better parent values for $i j$ th cross, $E M S=$ Error mean square.

\section{Results and Discussions}

\subsection{0-Grain Weight}

Highly significant differences $(\mathrm{P} \leq 0.01)$ among the genotypes, parents and the contrast between parents $\times$ crosses have been shown by analysis of variance for 1000 -grain weight (Table 2) however there were non-significant variations $(P \geq 0.05)$ among the crosses. Highly significant differences were also found among water regimes and the contrast between genotypes and water regimes and parent $\times$ water regimes and cross whereas the interaction of crosses and water regimes showed non-significant results. (Table 3) showed that the parent Lasani-08 has the highest value for this trait while Pari-73 has the lowest mean value for 1000-grain weight under normal condition. Among the $F_{1}$ hybrids, the highest mean value was shown by Lasani- $08 \times$ Pak- 81 and the cross Sehr-06 $\times$ Blue Silver showed the lowest mean value for 1000-grain weightwhereas in water stress condition Pak-81 showed highest mean value for 1000-grain weight and SA-42 has lowest mean value among the parents. Among the $\mathrm{F}_{1}$ hybrids Fsd- $08 \times$ Chenab-70 has the highest value for this trait and Pasban-90 $\times$ Sehr-06 has lowest mean value for 1000-grain weight under water stress condition. While for heterosis over the mid parent (Table 3) three crosses showed an increase over their respective mid parents under normal condition indicating significant heterosis $(\mathrm{P} \leq 0.05)$. The heterosis ranged from $6.55 \%$ (Lasani- $08 \times$ Pak-81) to $11.67 \%$ (Pari- $73 \times$ $\mathrm{C}-273)$. As far as heterosis over better parent is concerned only one cross Pari-73 $\times$ C-273 showed an increase over the better parent. The potence ratio Table 2 for 1000-grain weight showed that thirteen hybrids showed heterosis due to over dominance effect. The highest value of over dominance gene action was shown by the cross combination SA- $42 \times$ Fsd- 08 . For heterosis in water stress condition eleven crosses showed an increase over their mid parental values indicating significant heterosis and the range of heterosis was from 9.08\% (Sehr-06 $\times$ Blue Silver) to $26.60 \%$ (Fsd-08 $\times$ Chenab-70). Three crosses showed an increase over their respective better parents and showed significant positive heterosis over their respective better parents $(\mathrm{P} \leq 0.05)$. The range of positive heterobeltiosis was from $9.77 \%$ (Blue Silver $\times$ Sehr-06) to $13.19 \%($ Sehr-06 $\times$ Pasban90). In case of water stress twelve crosses showed heterosis due to over dominance effect. The highest value for over dominance effect was shown by the cross combination Fsd- $08 \times$ Chenab-70. The highest heterosis for this trait was again observed in crosses i.e. between post green revolution period and pre-green revolution period (Pari-73 $\times$ C-273) under non-stress condition. Pre-green revolution cultivars were indigenous to our area; they were tall and normally lodge at the maturity. On the other hand, post green revolution cultivars were introduced from CIMMYT. Thus because of geographical distance, they may have able to show higher magnitude of hetero-

Table 2. Analyses of variance for 1000 -grain weight and Stem reserve mobilization.

\begin{tabular}{cccc}
\hline SOV & df & 1000-gain weight & SRM \\
\hline Genotypes (G) & 27 & $3.29^{* *}$ & $0.55^{* *}$ \\
Parents (P) & 11 & $3.97^{* *}$ & $0.67^{* *}$ \\
Crosses (Cr) & 15 & $1.97^{\mathrm{NS}}$ & $0.14^{* *}$ \\
P vs. Cr & 1 & $15.42^{* *}$ & $5.54^{* *}$ \\
Water & 1 & $13091.18^{* *}$ & $43.19^{* *}$ \\
Regimes(W) & & $4.86^{* *}$ & $0.38^{* *}$ \\
G $\times$ W & 27 & $7.57^{* *}$ & $0.41^{* *}$ \\
P $\times$ W & 11 & $1.94^{\mathrm{NS}}$ & $0.30^{* *}$ \\
Cr $\times$ W & 15 & $18.79^{* *}$ & $1.15^{* *}$ \\
P vs. Cr $\times$ W & 1 & 1.54 & 0.02 \\
Error & 112 & &
\end{tabular}

Genotypic differences were highly significant $(\mathrm{P} \leq 0.01)$. NS $=$ Non significant. 
Table 3. Mean performance of parental lines, hybrids and estimation of percent heterosis, heterobeltiosis and potency ratio for 1000 -grain weight $(\mathrm{g})$ in wheat.

\begin{tabular}{|c|c|c|c|c|c|c|c|c|c|c|c|c|}
\hline \multirow{2}{*}{ Crosses } & MAT & MAT & PAT & PAT & $\mathbf{F} 1$ & F1 & HT & HT & HB & HB & PR & PR \\
\hline & $\mathbf{N}$ & WS & $\mathbf{N}$ & WS & $\mathbf{N}$ & WS & $\mathbf{N}$ & WS & $\mathbf{N}$ & WS & $\mathbf{N}$ & WS \\
\hline Sehr-06 $\times$ Pasban-90 & 31.46 & 12.36 & 32.79 & 11.03 & 33.24 & 13.99 & $3.45^{\mathrm{NS}}$ & $19.57^{*}$ & $1.37^{\mathrm{NS}}$ & $13.19^{*}$ & 1.68 & 3.45 \\
\hline Pasban-90 $\times$ Sehr-06 & 32.79 & 11.03 & 31.46 & 12.36 & 32.93 & 13.01 & $2.49^{\mathrm{NS}}$ & $11.20^{*}$ & $0.43^{\mathrm{NS}}$ & $5.26^{\mathrm{NS}}$ & 1.21 & 1.98 \\
\hline C-273 $\times$ Pari-73 & 29.38 & 13.64 & 28.17 & 12.06 & 30.55 & 14.06 & $6.15^{\mathrm{NS}}$ & $9.41^{*}$ & $3.98^{\mathrm{NS}}$ & $3.08^{\mathrm{NS}}$ & 2.94 & 1.53 \\
\hline Pari-73 $\times$ C-273 & 28.17 & 12.06 & 29.38 & 13.64 & 32.14 & 13.33 & $11.67^{*}$ & $3.73^{\mathrm{NS}}$ & $9.39^{*}$ & $-2.27^{\mathrm{NS}}$ & 5.56 & 0.61 \\
\hline SA-42 $\times$ Fsd- 08 & 31.54 & 10.30 & 31.21 & 12.14 & 32.66 & 13.71 & $4.08^{\mathrm{NS}}$ & $22.19^{*}$ & $3.55^{\mathrm{NS}}$ & $12.93^{*}$ & 7.79 & 2.71 \\
\hline Fsd- $08 \times$ SA-42 & 31.21 & 12.14 & 31.54 & 10.30 & 31.99 & 13.67 & $1.94^{\mathrm{NS}}$ & $21.84^{*}$ & $1.43^{\mathrm{NS}}$ & $12.6^{\mathrm{NS}}$ & 3.75 & 2.66 \\
\hline Fsd-08 $\times$ Chenab-70 & 31.21 & 12.14 & 29.98 & 12.52 & 30.80 & 15.61 & $0.65^{\mathrm{NS}}$ & $26.60^{*}$ & $-1.31^{\mathrm{NS}}$ & $24.7^{\mathrm{NS}}$ & 0.34 & 17.3 \\
\hline Chenab- $70 \times$ Fsd- 08 & 29.98 & 12.52 & 31.21 & 12.14 & 30.89 & 13.47 & $0.95^{\mathrm{NS}}$ & $9.24^{*}$ & $-1.03^{\mathrm{NS}}$ & $7.59^{\mathrm{NS}}$ & 0.48 & 6.00 \\
\hline Sehr- $06 \times$ Blue Silver & 31.46 & 12.36 & 30.73 & 13.41 & 30.09 & 14.06 & $-3.25^{\mathrm{Ns}}$ & $9.08^{*}$ & $-4.35^{\mathrm{NS}}$ & $4.85^{\mathrm{NS}}$ & -2.8 & 2.24 \\
\hline Blue Silver $\times$ Sehr-06 & 30.73 & 13.41 & 31.46 & 12.36 & 32.27 & 14.72 & $3.76^{\mathrm{NS}}$ & $14.20^{*}$ & $2.57^{\mathrm{NS}}$ & $9.77^{*}$ & 3.22 & 3.50 \\
\hline Lasani-0 $8 \times$ Pak- 81 & 34.19 & 11.92 & 31.49 & 14.44 & 34.99 & 13.51 & $6.55^{*}$ & $2.50^{\mathrm{NS}}$ & $2.34^{\mathrm{NS}}$ & $-6.44^{\mathrm{NS}}$ & 1.59 & 0.26 \\
\hline Pak- $81 \times$ Lasani- 08 & 31.49 & 14.55 & 34.19 & 11.92 & 33.29 & 13.27 & $1.37^{\mathrm{NS}}$ & $0.23^{\mathrm{NS}}$ & $-2.63^{\mathrm{NS}}$ & $-8.80^{\mathrm{NS}}$ & 0.33 & 0.03 \\
\hline Uqab-2000 $\times$ Pothowar-3 & 30.87 & 13.61 & 29.90 & 13.17 & 31.31 & 13.65 & $3.0^{\mathrm{NS}}$ & $1.94^{\mathrm{NS}}$ & $1.43^{\mathrm{NS}}$ & $0.29^{\mathrm{NS}}$ & 1.90 & 1.20 \\
\hline Pothowar-73 $\times$ Uqab-2000 & 29.90 & 13.17 & 30.87 & 13.61 & 31.52 & 14.69 & $3.72^{\mathrm{NS}}$ & $9.70^{*}$ & $2.11^{\mathrm{NS}}$ & $7.94^{\mathrm{NS}}$ & 2.34 & 5.89 \\
\hline Pasban-90 × Pak-81 & 32.79 & 11.03 & 31.49 & 14.44 & 30.83 & 13.43 & $-4.08^{\mathrm{NS}}$ & $5.42^{\mathrm{NS}}$ & $-5.98^{\mathrm{NS}}$ & $-6.99^{\mathrm{NS}}$ & -2.0 & 0.41 \\
\hline Pak-81 × Pasban-90 & 31.49 & 14.44 & 32.79 & 11.03 & 34.48 & 15.26 & $7.28^{*}$ & $19.78^{*}$ & $5.15^{\mathrm{NS}}$ & $5.68^{\mathrm{NS}}$ & 3.60 & 1.48 \\
\hline
\end{tabular}

MAT $=$ Maternal, PAT $=$ Paternal, $\mathrm{F} 1=$ First generation, $\mathrm{HT}=$ Heterosis, $\mathrm{HB}=$ Heterobeltiosis, $\mathrm{PR}=$ Potence Ratio, $\mathrm{N}=$ Normal, WS $=$ Water stress, Least significant differences among the mean value of parents and $\mathrm{F}_{1} \pm 2.01$.

sis. Previous findings have also shown positive relationship between genetic distance and heterosis in crop plants as consistent with Tao et al. [19]. The hybrid Pari-73 $\times$ C-273 showed the highest values for heterosis and heterobeltiosis under normal condition while the hybrid Fsd-08 $\times$ Chenab-70 showed the highest values for heterosis in water stress condition. Heterosis and heterobeltiosis for 1000 -grain weight in variability values has also been reported by Baric et al. [20]; Mahmood et al. [21]; Akbar et al. [22] and Tuhina-Khatun et al. [23].

\subsection{Stem Reserve Mobilization}

Stem reserves have been shown to supply the nutrient to the developing seed when plants are unable to synthesize their food under severe water shortage [13]. It was noted that drought tolerant genotypes have higher fructan contents in their main stem and they unloaded these nutrients to the sink i.e. seed thus providing some sustainability to the yield under water stress conditions. The analysis of variance for stem reserve mobilization (Table 2) showed highly significance differences among the genotypes and due to its components i.e., parents, crosses and the contrast of parents $\times$ crosses $(P \leq 0.01)$. Previous finding have also showed variation within wheat germplasm for stem reserve mobilization [13,24]. Highly significant differences were found between water regimes and all its interactions $(\mathrm{P} \leq 0.01)$. Individual comparison of means (Table 3) showed that the parent Chenab-70 has the highest value for this trait while C-273 has the lowest mean value for stem reserve mobilization under normal condition. Among the $\mathrm{F}_{1}$ hybrids, the cross Uqab-2000 $\times$ Pothowar-73 showed the highest mean value and the cross SA-42 $\times$ Fsd-08 showed the lowest mean value for this trait whereas in water stress condition Pari-73 showed the highest mean value and SA-42 has the lowest mean value among the parents. Among the $\mathrm{F}_{1}$ hybrids C-273 $\times$ Pari-73 has the highest value for this trait and Uqab-2000 $\times$ Pothowar-73 showed the lowest mean value for stem reserve mobilization in water stress condition. For heterosis over the mid parent twelve crosses showed an increase over their respective mid parents (Table 4) under normal condition. Twelve crosses showed significant heterosis $(\mathrm{P} \leq 0.05)$. The heterosis ranged from $-26.11 \%(\mathrm{SA}-42 \times \mathrm{Fsd}-2008)$ to $84 \%$ (Sehar-06 $\times$ Pasban-90). Eight crosses manifested an increase over the better parent. The range of heterobeltiosis was from $-37.97 \%$ (SA-42 $\times$ Fsd-2008) to $83.16 \%$ (Sehr-06 $\times$ Pasban-90). The potence ratio table for stem reserve mobilization (Table 4) showed that almost all hybrids, heterosis was due to over dominance effect except four crosses which showed partial dominance. The range of potence ratio was from -1.37 (SA-42 $\times$ Fsd-08) to 94.5 (Sehr-06 $\times$ Pasban-90). Under water stress conditions twelve crosses showed increase over their mid parental values and the heterosis values ranged from $2.94 \%$ (Lasani-08-08 $\times$ Pak-81) to $93.47 \%$ (Sehr-06 $\times$ Pasban90). Six crosses showed an increase over their respective 
Table 4. Mean performance of parental lines, hybrids and estimation of percent heterosis, heterobeltiosis and potency ratio for stem reserve mobilization in wheat.

\begin{tabular}{|c|c|c|c|c|c|c|c|c|c|c|c|c|}
\hline \multirow{2}{*}{ Crosses } & MAT & MAT & PAT & PAT & F1 & F1 & HT & HT & HB & HB & PR & PR \\
\hline & $\mathrm{N}$ & WS & $\mathrm{N}$ & WS & $\mathrm{N}$ & WS & $\mathrm{N}$ & WS & $\mathrm{N}$ & WS & $\mathrm{N}$ & WS \\
\hline Sehr- $06 \times$ Pasban-90 & 1.12 & 0.57 & 1.13 & 0.35 & 2.07 & 0.89 & $84.00^{*}$ & $93.47^{*}$ & $83.16^{*}$ & $56.14^{*}$ & 94.5 & 3.9 \\
\hline Pasban-90 $\times$ Sehr-06 & 1.13 & 0.35 & 1.12 & 0.57 & 1.91 & 0.6 & $69.78^{*}$ & $30.43^{\mathrm{NS}}$ & $69.02^{*}$ & $5.26^{\mathrm{NS}}$ & 79.0 & 1.27 \\
\hline C-273 $\times$ Pari-73 & 0.33 & 0.66 & 1.89 & 1.20 & 1.90 & 1.22 & $71.17^{*}$ & $31.18^{*}$ & $0.53^{\mathrm{NS}}$ & $1.67^{\mathrm{NS}}$ & 1.01 & 1.07 \\
\hline Pari-73 $\times$ C-273 & 1.89 & 1.2 & 0.33 & 0.66 & 1.88 & 1.20 & $69.40^{*}$ & $29.03^{*}$ & $-0.53^{\mathrm{NS}}$ & $0.00^{\mathrm{NS}}$ & 0.98 & 1.00 \\
\hline SA-42 $\times$ Fsd- 08 & 1.28 & 0.32 & 1.87 & 0.57 & 1.16 & 0.85 & $-26.11^{*}$ & $93.18^{*}$ & $-37.97^{*}$ & $49.12^{*}$ & -1.37 & 3.15 \\
\hline Fsd- $08 \times$ SA- 42 & 1.87 & 0.57 & 1.28 & 0.32 & 1.99 & 0.70 & $26.75^{*}$ & $59.09^{*}$ & $6.42^{\mathrm{NS}}$ & $22.81^{\mathrm{NS}}$ & 1.40 & 2.00 \\
\hline Fsd-08 $\times$ Chenab-70 & 1.87 & 0.57 & 2.14 & 0.67 & 2.04 & 0.66 & $2.00^{\mathrm{NS}}$ & $6.45^{\mathrm{NS}}$ & $-4.67^{\mathrm{NS}}$ & $-1.49^{\mathrm{NS}}$ & 0.28 & 0.80 \\
\hline Chenab-70 $\times$ Fsd- 08 & 2.14 & 0.67 & 1.87 & 0.57 & 2.15 & 0.95 & $7.50^{\mathrm{NS}}$ & $53.22^{*}$ & $0.47^{\mathrm{NS}}$ & $41.79^{*}$ & 1.07 & 6.60 \\
\hline Sehr-06 $\times$ Blue Silver & 1.12 & 0.57 & 1.37 & 0.48 & 1.86 & 0.74 & $50.00^{*}$ & $-29.52^{*}$ & $35.77^{*}$ & $29.82^{\mathrm{NS}}$ & 4.77 & 0.64 \\
\hline Blue Silver $\times$ Sehr-06 & 1.37 & 0.48 & 1.12 & 0.57 & 1.85 & 0.72 & $49.19^{*}$ & $-31.43^{*}$ & $35.03^{*}$ & $26.32^{\mathrm{NS}}$ & 4.69 & 0.68 \\
\hline Lasani-08 × Pak-81 & 0.73 & 0.54 & 1.96 & 0.83 & 1.89 & 0.70 & $41.04^{*}$ & $2.94^{*}$ & $-3.57^{\mathrm{NS}}$ & $-15.66^{\mathrm{NS}}$ & 0.88 & 0.13 \\
\hline Pak- $81 \times$ Lasani-08 & 1.96 & 0.83 & 0.73 & 0.54 & 1.97 & 0.89 & $47.02^{*}$ & $30.88^{*}$ & $0.51^{\mathrm{NS}}$ & $7.23^{\mathrm{NS}}$ & 1.01 & 1.40 \\
\hline Uqab-2000 $\times$ Pothowar-73 & 1.48 & 0.72 & 1.87 & 0.40 & 2.59 & 0.52 & $55.09^{\mathrm{NS}}$ & $-7.14^{\mathrm{NS}}$ & $38.50^{*}$ & $-27.78^{*}$ & 4.60 & -0.25 \\
\hline Pothowar-73 $\times$ Uqab-2000 & 1.87 & 0.40 & 1.48 & 0.72 & 1.62 & 1.04 & $-2.99^{\mathrm{NS}}$ & $85.71^{*}$ & $-13.37^{*}$ & $44.44^{*}$ & -0.25 & 3.00 \\
\hline Pasban- $90 \times$ Pak- 81 & 1.12 & 0.35 & 1.96 & 0.83 & 2.08 & 0.81 & $35.06^{*}$ & $37.28^{*}$ & $6.12^{\mathrm{NS}}$ & $-2.41^{\mathrm{NS}}$ & 1.28 & 0.92 \\
\hline Pak-81 × Pasban-90 & 1.96 & 0.83 & 1.12 & 0.35 & 2.53 & 0.60 & $64.29^{*}$ & $1.69^{\mathrm{NS}}$ & $29.08^{*}$ & $-27.71^{*}$ & 2.36 & 0.04 \\
\hline
\end{tabular}

MAT $=$ Maternal, PAT $=$ Paternal, F1 = First generation, HT $=$ Heterosis, HB $=$ Heterobeltiosis, PR $=$ Potence Ratio, $*=$ Significant, NS $=$ Non-significant, Least significant differences among the mean value of parents and $\mathrm{F} 1 \pm(0.23)$.

better parents and showed significant heterosis over their better parents $(\mathrm{P} \leq 0.05)$. The range of positive heterobeltiosis was from $41.79 \%$ (Chenab-70 $\times$ Fsd-08) to $56.14 \%$ (Sehr-06 $\times$ Blue Siver). Under water stress conditions nine crosses showed heterosis due to over dominance effect. The highest value for over dominance effect was shown by the cross Chenab-70 $\times$ Fsd-08. Drought depressed the mean values of SRM of many cultivars and their hybrids. When relationship of SRM with yield and its components was established, it showed moderately positive relationship with 1000 -grain weight $\left(R^{2}=0.20\right)$ showing its positive contribution toward yield compo nents of parental genotypes under water stress. This influence over the yield and yield component has also been observed in some previous studies in wheat as revealed by Farhangi and Ghodsi, [24]; Gupta et al. [13]. However, these authors were not able to show heterosis manifested as result of crossing of diverse parents. Most of the crosses induced significant heterosis and magnitude of heterosis increased under water stress thus showing the values of heterosis breeding under both conditions. Crosses showing significant positive heterosis may be exploited in both stress and non-stress condition for increasing wheat productivity. The genotypes possessing high mobilization of stem reserves are considered able to withstand sever water stress conditions because they have ability to accumulate sufficient amount of water soluble carbohydrates (WSC) in their stems and then able to shuffle carbohydrates at the presence of light in to grain filling under the limited or non-photosynthesis conditions $[25,26]$. The genotypes showing less SRM may not be able to withstand the shocks of water stress, and resultantly they will lose their yield potential at the onset of water stress [7,12,27,28].

\section{Conclusion}

This study reveals that stem reserves mobilization supports grain weight in wheat particularly if the water stress occurs. The elite genotypes like Sehr-06 $\times$ Pasban-90, Pari-73 $\times$ C-273, Fsd-08 $\times$ SA-42 may be used as breeding material to create genetic variation for stem reserves mobilization and to develop promising wheat varieties that will be more adapted to water stressed conditions.

\section{Acknowledgements}

The authors are grateful to Dr. AbdurRahman, Professor Emeritus, Ex-Vice Chancellor, University of Agriculture, Faisalabad, Pakistan, Prof. Dr. Pat Heslop Harrison and Dr. Trude Schwarzacher, University of Leicester, United Kingdom for their continuous guidance \& support to conduct the study and to prepare the manuscript. 


\section{REFERENCES}

[1] R. G. Jones, "Quality Requirements for Wheat Starch and Gluten Extraction. In: Aspects of Applied Biology 15Cereal Quality," Association of Applied Biologists, Warwick, 1987.

[2] Government of Pakistan, "Economic Survey of Pakistan," Finance Division, Economic Advisory Wing, Islamabad. 2011.

[3] D. A. Sleper and J. M. Poehlman, "Breeding Field Crops," 5th Edition, Iowa State University Press, 2006.

[4] S. Rauf, M. Shahzad, J. A. Teixeira da Silva and I. R. Noorka, "Biomass Partitioning in Sunflower (Helianthus annuus L.) Inbred Lines and Hybrids under Contrasting Saline Regimes," Journal of Crop Science and Biotechnology, Vol. 15, No. 3, 2011, pp. 53-57.

[5] A. Sharif, A. Bakhsh, M. Arshad, A. M. Haqqani and S. Najma, "Identification of Genetically Superior Hybrids in Chickpea (Cicer arietinum L.)," Pakistan Journal of Botany, Vol. 33, 2001, pp. 403-409.

[6] A. Kumar, V. K. Mishra, R. P. Vyas and V. Singh, "Heterosis and Combining Ability Analysis in Bread Wheat (Triticumaestivum L.)," Journal of Plant Breeding and Crop Science, Vol. 3, No. 10, 2011, pp. 209-217.

[7] M. A. Chowdhry, I. Rasool, I. Khaliq, T. Mehmood and M. M. Gilliani, "Genetics of Some Metric Traits in Spring Wheat under Normal and Drought Environments," Rachis, Barley and Wheat Newsletter, Vol. 18, No. 1, 1999, pp. 34-39.

[8] I. R. Noorka, S. Rehman, J. R. Haidry, I. Khaliq, S. Tabassam and M. Din, "Effect of Water Stress on PhysicoChemical Properties of Wheat (Triticumaestivum L.)," Pakistan Journal of Botany, Vol. 41, No. 6, 2009, pp. 2917-2924.

[9] A. Hameed, N. Bibi, J. Akhter and N. Iqbal, "Differential Changes in Antioxidants, Proteases, and Lipid Peroxidation in Flag Leaves of Wheat Genotypes under Different Levels of Water Deficit Conditions," Plant Physiology and Biochemistry, Vol. 49, 2011, pp. 178-185.

[10] I. R. Noorka and S. A. Shahid, "Use of Conservation Tillage System in Semiarid Region to Ensure Wheat Food Security in Pakistan," Development in Soil Salinity Assessment and Reclamation, Springer Book, 2013. http://www.springer.com/environmrnt/soil+science/book/ 978978-94-007-5683-0

[11] B. Ehdaie, G. A. Alloush, M. A. Madore and J. G. Waines, "Genotypic Variation for Stem Reserves and Mobilization in Wheat: I. Post Anthesis Changes in Inter Node Dry Matter," Crop Science, Vol. 46, No. 2, 2006, pp. 735-746. doi:10.2135/cropsci2005.04-0033

[12] I. R. Noorka, M. A. S. EL-Bramawy, S. Tabasum and A. R. Saljooqi, "Consumptive Use of Water and Genetical Assessment of Wheat Genotypes to Defy Worrisome Prevalence of Water Stress," Sarhad Journal of Agriculture, Vol. 28, No. 4, 2012, pp. 559-564.

[13] A. K. Gupta, K. Kaur and N. Kaur, "Stem Reserve Mobilization and Sink Activity in Wheat under Drought Conditions," American Journal of Plant Sciences, Vol. 2, 2011, pp. 70-77.
[14] A. Blum, "Improving Wheat Grain Filling under Stress by Stem Reserve Mobilization," Euphytica, Vol. 100, No. 1-3, 1998, pp. 77-83. doi:10.1023/A:1018303922482

[15] M. P. Reynolds, B. Skovamand, R. Trethowan and W. Pfeiffer, "Evaluating a Conceptual Model for Drought Tolerance," In: J. M. Ribaut, Ed., Using Molecular Markers to Improve Drought Tolerance, CIMMYT, Mexico, 1999.

[16] I. R. Noorka, "Sustainable Rural Development and Participatory Approach by On-Farm Water Management Techniques," Sustainable Agricultural Development, Springer, New York, 2011, pp. 139-146.

[17] R. G. D. Steel, J. H. Torrie and D. A. Dicky, "Principles and Procedures of Statistics. A Biological Approach," McGraw Hill Brook Co., New York, 1997, pp. 336-354.

[18] S. Fonseca and F. L. Patterson, "Hybrid Vigour in Seven Parent Diallel Crosses in Common Wheat (Triticumaestivum L.)," Crop Science, Vol. 8, 1968, pp. 85-89. doi:10.2135/cropsci1968.0011183X000800010025x

[19] T. Zhang, X.-L. Ni, K.-F. Jiang, Q.-H. Yang, L. Yang, X.-Q. Wan, Y.-J. Cao and J.-K. Zheng, "Correlation between Heterosis and Genetic Distance Based on Molecularmarkers of Functional Genes in Rice," Rice Science, Vol. 17, No. 4, 2010, pp. 288-295. doi:10.1016/S1672-6308(09)60029-9

[20] M. Baric, H. Sarcevic and S. Keresa, "Analysis of Yield Components of $F_{1}$ Hybrids of Crosses between Spring and Winter Wheat Types (Triticumaestivum L.)," Agriculturae Conspectus Scientificus, Vol. 69, No. 1, 2004, pp. 87-94.

[21] Q. Mahmood, W. D. Lei, A. S. Qureshi, M. R. Khan, W. Hayat, G. Jillani, I. H. Shamsi, M. A. Tajjamal and M. D. Khan, "Heterosis, Correlation, and Path Analysis of Morphological and Biochemical Characters in Wheat," Journal of Agricultural, Vol. 1, No. 3, 2006, pp. 180-185.

[22] M. Akbar, M. A. Khan, A. U. Rehman and N. Ahmad, "Heterosis and Heterobeltiosis for Improvement of Wheat Grain Yield," Journal of Agricultural Research, Vol. 45, No. 2, 2007, pp. 87-94.

[23] M. Tuhina-Khatun, M. A. A. Bari, M. A. Zaman, H. Begum and S. Akter, "Heterosis Estimates in $\mathrm{F}_{2}$ Diallel Population of Spring Wheat at Two Different Cultural Conditions," Bangladesh Journal of Agricultural Research, Vol. 35, No. 3, 2010, pp. 413-422.

[24] S. Farhangi and M. Ghodsi, "The Contribution of Remobilization of Storage Materials in Wheat Yield as Affected by Potassium Iodide (KI)," International Journal of Plant Physiology and Biochemistry, Vol. 3, No. 3, 2011, pp. 60-63.

[25] M. E. Nicolas and N. C. Turner, "Use of Chemical Desiccant and Senescing Agents to Select Wheat Lines Maintaining Grain Size during Postanthesis Drought," Field Crops Research, Vol. 31, No. 1-2, 1993, pp. 155-171. doi:10.1016/0378-4290(93)90058-U

[26] M. Mohammadi, R. A. Karimizadeh and M. R. Naghavi, "Selection of Bread Wheat Genotypes against Heat and Drought Tolerance on the Base of Chlorophyll Content and Stem Reserves," Journal of Agriculture and Social Sciences, Vol. 5, 2009, pp. 119-122. 
[27] J. Yang, R. G. Sears, B. S. Gil and G. M. Paulsen, "Genotypic Differences in Utilization of Assimilate Sources during Maturation of Wheat under Chronic Heat and Heat Shock Stresses," Euphytica, Vol. 125, No. 2, 2002, pp. 179-188. doi:10.1023/A:1015882825112

[28] Z. Plaut, B. J. Butow, C. S. Blumenthal and C. W. Wrig- ley, "Transport of Dry Matter into Developing Wheat Kernels and Its Contribution to Grain Yield under PostAnthesis Water Deficit and Elevated Temperature," Field Crops Research, Vol. 86, No. 2-3, 2004, pp. 185-198. doi:10.1016/i.fcr.2003.08.005 